\title{
Thermal and Moisture Expansion Studies of Some Domestic Granites
}

\author{
By Arthur Hockman and Daniel W. Kessler
}

\begin{abstract}
As a part of a study of the physical properties of building stone, thermal expansion determinations were made on 48 samples of domestic granites by the differential interferometer method (with an interferograph recording attachment) over the temperature range $-20^{\circ}$ to $+60^{\circ} \mathrm{C}$. Thermal coefficients computed between $-20^{\circ}$ and $+60^{\circ} \mathrm{C}$ ranged from 4.8 to $8.3 \times 10^{-6}$ per deg $\mathrm{C}$ with an average of $6.2 \times 10^{-6}$ per deg C. Coefficients obtained on cooling $\left(60^{\circ}\right.$ to $\left.0^{\circ} \mathrm{C}\right)$ averaged $6.7 \times 10^{-6}$ per deg $\mathrm{C}$. Expansion curves drawn for all samples indicate slight irregularities in the 0 - to 20 -deg range in the heating curves of at least 65 percent of the samples. These irregularities are probably caused by moisture changes in the sample during the test.

Moisture expansion determinations were made on the 48 samples by means of the Tuckerman optical strain gage over a 24-hour period at constant temperature. The expansions obtained ranged from 0.0004 to 0.009 percent and averaged 0.0039 percent.

Adverse effects resulting from continued thermal and moisture expansion and contraction of granite are believed to be of some significance in monumental structures that are expected to last for long periods of time.
\end{abstract}

\section{Introduction}

Granite is known to be one of the most durable of structural materials. For this reason it has been an ideal choice for monuments, public buildings, shrines, and structures that are expected to last for centuries. There are granite structures in this country that have existed for periods up to $200 \mathrm{yr}$ without showing serious signs of disintegration, yet there is evidence to show that some granite structures have begun to deteriorate in less than $50 \mathrm{yr}$.

The durability of granite may be adversely affected by one or more of many physical and chemical agencies. The effect of natural temperature changes in contributing to the deterioration of the stone has been recognized by geologists and engineers. ${ }^{1}$ It is well known that the rapid heating of granite, as in the case of a fire, will usually cause serious spalling. Not so apparent is the fact that gradients in a granite structure

\footnotetext{
${ }_{1}$ The supposition that rocks in general are seriously affected by natural changes in temperature is strongly challenged by some geologists. For example see E. Blackwelder, The insolation hypothesis of rock weathering Am. J. Sci, 26, 970 (1933).
}

resulting from the usual diurnal temperature changes cause internal stresses which, after numerous repetitions, may have a weakening effect on the stone. It also seems likely that the granite may be affected by the unequal expansion of the different mineral constituents, and the fact that the principal constituents, namely feldspar and quartz, expand unequally along different crystallographic axes.

Expansion effects due to absorption of water by granite have not been generally understood or appreciated. The experimental data acquired in this study definitely prove that granite undergoes a change in length on becoming wet. As in the case of thermal expansion, the repeated expansion and contraction resulting from wetting and drying may have a weakening effect on the stone. Moisture gradients resulting from partial wetting of the stone cause internal stresses, which in the course of time may adversely affect its durability.

The purpose of this study was to accumulate data on the thermal expansion characteristics of granite over the temperature range produced by 
the usual weather exposures and also on the expansion due to the absorption of water. Most of the published data on thermal expansion of granite were computed from measurements taken at larger temperature intervals than those to which masonry is normally subjected, and these values can be misleading when applied to the seasonal range. In this study coefficients of linear thermal expansion were determined over the range of $-20^{\circ}$ to $+60^{\circ} \mathrm{C}\left(-4^{\circ}\right.$ to $\left.140^{\circ} \mathrm{F}\right)$. Since there are very few data published on the moisture expansion of granite, this property was determined on the entire series of samples tested for thermal expansion. This report cites a few examples of granite structures that show some deterioration resulting from temperature and moisture effects.

\section{Previous Investigations}

A review of the literature on thermal expansion measurements of granite reveals that in 1832, Bartlett $[1]^{2}$ seeking the cause of fissures in coping joints in a granite structure, measured the thermal expansion of a sample of Massachusetts granite, and samples of marble and limestone. His specimens were $94 \mathrm{in}$. long, and the temperature range was $-14^{\circ}$ to $+39^{\circ} \mathrm{C}$. (See table 1 for results of previous investigations). Also about this time, Adie [2] measured the expansion of two granites (Aberdeen gray and Peterhead red from Scotland), also samples of marble, sandstone, and greenstone. His temperature range was $+10^{\circ}$ to $98^{\circ} \mathrm{C}$. Adie recognized that a sample of greenstone expanded permanently after several successive heatings. Reade [3] in 1886 , included four samples of granite in his thermal expansion studies of several types of rocks but did not state the temperature range. In 1895 at the Watertown Arsenal [4] thermal expansion tests were made on eleven samples of granite acquired from eight states. Measured bars, $24 \mathrm{in.} \mathrm{by} 6$ in. by $4 \mathrm{in}$. were placed in cold water $\left(32^{\circ} \mathrm{F}\right)$, then in hot water $\left(212^{\circ} \mathrm{F}\right)$, and back in the cold bath. These expansion results evidently represented the combined effects of temperature and moisture.

In 1909 Baldwin-Wiseman and Griffith [5] determined permanent length changes, due to heating, for several samples of sandstones, lime-

\footnotetext{
${ }^{2}$ Figures in brackets indicate the literature references at the end of this paper.
}

TABLE 1. Summary of thermal expansion data on granite obtained by previous investigators

\begin{tabular}{|c|c|c|c|c|}
\hline $\begin{array}{l}\text { No. of } \\
\text { specimens } \\
\text { tested }\end{array}$ & $\begin{array}{l}\text { Temperature } \\
\text { range a }\end{array}$ & $\begin{array}{c}\text { Mean co- } \\
\text { efficient of } \\
\text { linear ther- } \\
\text { mal expan- } \\
\text { sion per } \\
\text { degree } \\
\mathrm{C} \times 10^{6}\end{array}$ & Investigator & $\begin{array}{l}\text { Date of } \\
\text { public- } \\
\text { ation }\end{array}$ \\
\hline 1. & $\begin{array}{c}{ }^{\circ} \mathrm{C} \\
-14 \text { to }+39\end{array}$ & 8. 25 & Bartlett_ & 1832 \\
\hline $2 \ldots \ldots$ & +10 to 98 & 8.22 & Adie........... & 1836 \\
\hline $4 \ldots$. & (. & 8.85 & Reade & 1886 \\
\hline $11 \ldots$ & 0 to 100 & b 7.0 & Watertown Arsenal ....... & 1895 \\
\hline $1 \ldots \ldots$ & 0 to 100 & 10.2 & $\begin{array}{l}\text { Baldwin-Wiseman \& } \\
\text { Griffith. }\end{array}$ & 1909 \\
\hline $1 \ldots$ & +19 to 172 & 8. 6 & Wheeler & 1910 \\
\hline $20 \ldots$ & 0 to 100 & 8.1 & Griffith & 1936 \\
\hline $5 \ldots$ & 3 to 60 & 6. 7 & Willis \& DeReus & 1939 \\
\hline $4 \ldots$ & -20 to 60 & 6. 0 & Johnson \& Parsons & 1944 \\
\hline
\end{tabular}

a The range for which the coefficients were calculated.

$\mathrm{b}$ Specimens tested in wet condition.

stones, marbles, and one sample of granite (Peterhead, Scotland). The temperature range was $+20^{\circ}$ to $300^{\circ} \mathrm{C}$. In 1910 , Wheeler [6] studied the effects of six repeated heatings from $+19^{\circ}$ to $1,000^{\circ} \mathrm{C}$ of samples of Rhode Island granite, Canadian diabase, and of Italian marble from $+19^{\circ}$ to $500^{\circ} \mathrm{C}$.

The more recent investigations of thermal expansion include those made in 1936 by Griffith [7]. Among the 106 samples of American rocks tested by him, about 20 represent granites generally used for building and monumental purposes. His range was room temperature to $260^{\circ} \mathrm{C}$.

In 1939, Willis and DeReus [8] included the measurements of five samples of granite in their study of concrete aggregate. The temperature range was $+3^{\circ}$ to $60^{\circ} \mathrm{C}$. In 1944 , Johnson and Parsons [9], applying a test procedure similar to that used in the present investigation, included the measurements of four granite samples in their study of thermal expansion of concrete aggregates.

Comparatively few investigators have studied the moisture expansion of building stone. It seems that in 1886 Schumann [10] (original reference unobtainable) was the first to make a systematic study of moisture expansion of natural stone. Hirschwald [11] repeated these experiments. Using a micrometer microscope, the latter determined length changes of several stone specimens after 2 weeks immersion in water. The average expansion obtained for one sample of granite and four samples of basalt was 0.029 percent. 
More recent studies of moisture expansion of building stone include those made by Matsumoto [12], Stradling [13], Royan [14], and Kessler [15]. However, the reports of these investigators did not include any data on granite.

An examination of all the published data on thermal and moisture expansion of granites described in the preceding paragraphs reveals; (1) there is a scarcity of data on the thermal expansion characteristics of domestic granites over the seasonal range of temperature; (2) investigators took readings at wide temperature intervals and few made observations on cooling; (3) there are practically no data available on dimensional changes in domestic granites due to absorption of moisture.

\section{Description of Samples}

The 48 samples used in this study were collected for a previous investigation at this Bureau of other physical properties of the domestic granites [16]. The samples represent the deposits of the principal producing districts of 17 states. Most of these granites have been used for architectural, monumental, or structural purposes.

Geologically, granite is designated as a crystalline rock of igneous origin, and is composed of feldspar, quartz, and one or more accessory minerals such as mica, hornblende, pyroxene, etc. Generally, there are two kinds of feldspar present in the rock, the more abundant usually being a potash feldspar (orthoclase or microcline or both). The other is soda-lime feldspar (plagioclase), and may include one or more of the following species: albite, oligoclase, and andesine. In most granites, quartz ranks second in abundance to the feldspars, a ferro-magnesian mineral (biotite, hornblende, or pyroxene) ranking third. The term "commercial granite" may include such closely related rocks as gneiss, syenite, monzonite, etc. "Black granites", also a commercial designation, include rock species such as diabase, norite, and gabbro, which are somewhat distantly related to the true granites. This study includes several of these "related" granites. Of the 48 granites tested, potash feldspar was the most abundant mineral in 35 samples, soda-lime feldspar in 10, and quartz in 3. Mica was the most abundant of the accessory minerals in 39 samples, hornblende in 4 , and pyroxene in 2.

The descriptive portion of table 2 gives the sample numbers, source, classification, texture, and major mineral constituents of all samples tested. The "classification" of a granite is derived from the most abundant accessory mineral, such as "biotite granite," or "hornblende granite", etc. Textures refers to the average size of the feldspar grains and follows the scale given at the end of the table.

TABLE 2. Description, source, classification, texture, composition, thermal expansion coefficients, and moisture expansion percentages of all samples tested

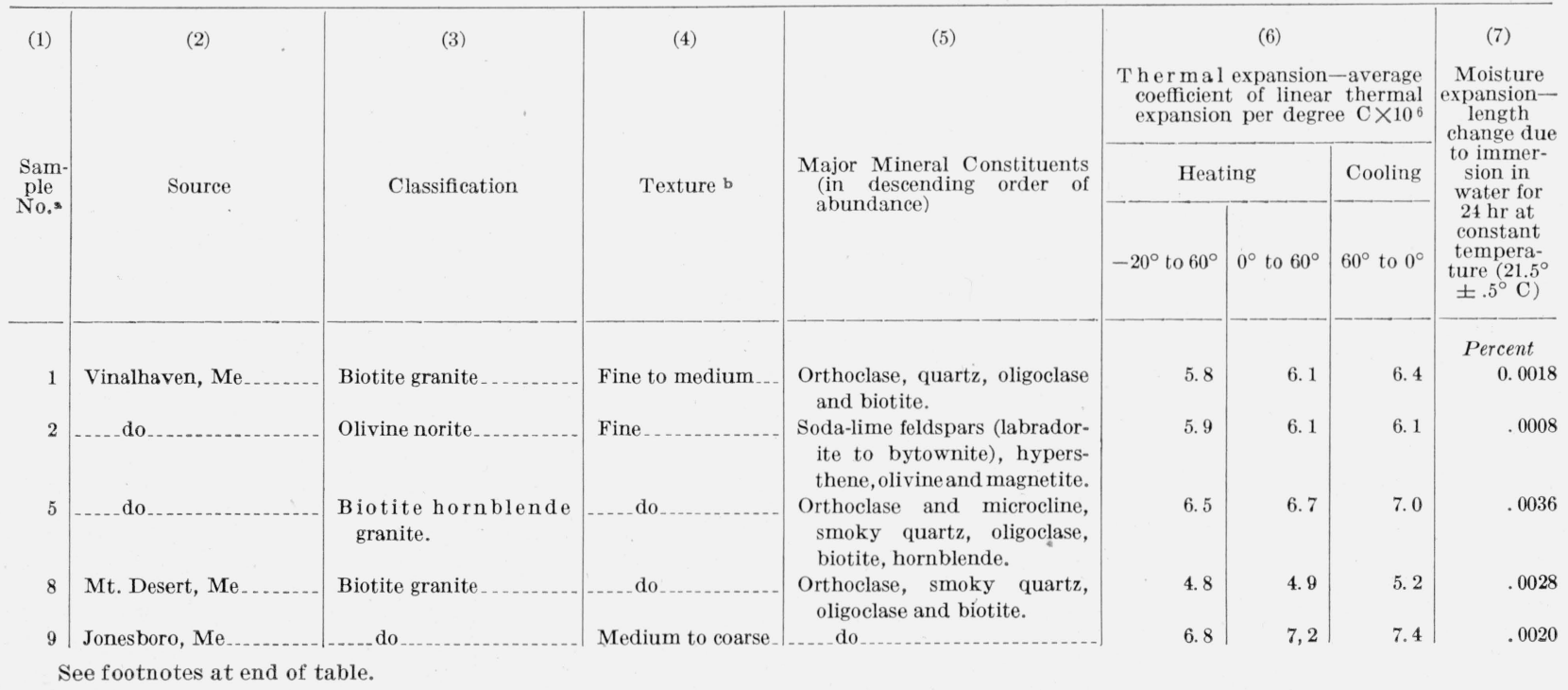


TABLE 2. Description, source, classification, texture, composition, thermal expansion coefficients, and moisture expansion percentages of all samples tested-Continued

\begin{tabular}{|c|c|c|c|c|c|c|c|c|}
\hline \multirow{3}{*}{$\begin{array}{l}\text { Sam- } \\
\text { ple } \\
\text { No. }\end{array}$} & \multirow{3}{*}{ Source } & \multirow{3}{*}{ Classification } & \multirow{3}{*}{ Texture b } & \multirow{3}{*}{$\begin{array}{l}\text { Major Mineral Constituents } \\
\text { (in descending order of } \\
\text { abundance) }\end{array}$} & \multicolumn{3}{|c|}{$\begin{array}{l}\text { Therma l expansion-average } \\
\text { coefficient of linear thermal } \\
\text { expansion per degree } \mathrm{C} \times 10^{\circ}\end{array}$} & \multirow{3}{*}{$\begin{array}{l}(7) \\
\text { Moisture } \\
\text { expansion- } \\
\text { length } \\
\text { change due } \\
\text { to immer- } \\
\text { sion in } \\
\text { water for } \\
24 \mathrm{hr} \text { at } \\
\text { constant } \\
\text { tempera- } \\
\text { ture }\left(21.5^{\circ}\right. \\
\left. \pm .5^{\circ} \mathrm{C}\right)\end{array}$} \\
\hline & & & & & Heati & ing & Cooling & \\
\hline & & & & & $-20^{\circ}$ to $60^{\circ}$ & $0^{\circ}$ to $60^{\circ}$ & $60^{\circ}$ to $0^{\circ}$ & \\
\hline 10 & Long Cove, Me & Biotite-muscovite granite.. & Fine to medium & $\begin{array}{l}\text { Microcline and orthoclase, } \\
\text { quartz, oligoclase, biotite } \\
\text { and muscovite. }\end{array}$ & 6. 6 & 6.5 & 7.1 & $\begin{array}{l}\text { Percent } \\
\quad 0.0068\end{array}$ \\
\hline 12 & Stonington, Me & Biotite granite & Coarse .............. & $\begin{array}{l}\text { Orthoclase and microcline, } \\
\text { smoky quartz, oligoclase, } \\
\text { and biotite. }\end{array}$ & $\begin{array}{l}\text { 6. } 2 \\
5.9\end{array}$ & $\begin{array}{l}6.3 \\
6.0\end{array}$ & $\begin{array}{l}6.5 \\
6.4\end{array}$ & $\begin{array}{l}.0028 \\
.0020\end{array}$ \\
\hline 16 & Highpine, Me ...... & do & Coarse . . . . . & $\begin{array}{l}\text { Microcline and orthoclase, } \\
\text { smoky quartz, oligoclase, } \\
\text { and biotite. }\end{array}$ & $\begin{array}{l}0.0 \\
5.8\end{array}$ & $\begin{array}{l}1.1 \\
5.9\end{array}$ & 6.3 & .0080 \\
\hline 17 & Concord, N. H ........ & Muscovite-biotite granite_- & Fine to medium & $\begin{array}{l}\text { Microcline and orthoclase, } \\
\text { quartz, oligoclase-albite, } \\
\text { muscovite, and biotite. }\end{array}$ & 7.7 & 7.7 & 8.4 & .0048 \\
\hline 18 & Redstone, N. H & Biotite-granite ............. & Coarse ... & $\begin{array}{l}\text { Orthoclase, smoky quartz (oli- } \\
\text { goclase-albite), and biotite. }\end{array}$ & 5.4 & 5.6 & 6.1 & .0022 \\
\hline 21 & Milford, N. H... & Quartz monzonite_...... & Fine ..... & $\begin{array}{l}\text { Microcline and orthoclase, oli- } \\
\text { goclase, smoky quartz and } \\
\text { biotite. }\end{array}$ & 5. 7 & 6.0 & 6.3 & .0030 \\
\hline 24 & Fitzwilliams, N. H & $\begin{array}{l}\text { Biotite-muscovite } \\
\text { granite. }\end{array}$ & _..... do do........ & $\begin{array}{l}\text { Orthoclase and microcline, } \\
\text { quartz, oligoclase, biotite } \\
\text { and muscovite. }\end{array}$ & 5.4 & 5.5 & 6. 2 & .0084 \\
\hline 25 & Barre, $\mathrm{Vt}_{\ldots . . .}$ & Biotite granite... & ..... do & $\begin{array}{l}\text { Orthoclase, smoky quartz, } \\
\text { oligcclase-albite, biotite and } \\
\text { muscovite. }\end{array}$ & 6.3 & 6.1 & 6.8 & .0050 \\
\hline 27 & Derby, $\mathrm{Vt}_{\ldots} \ldots$ & Quartz monzonite & Fine to medium & $\begin{array}{l}\text { Smoky quartz, oligoclase, mi- } \\
\text { crocline and orthoclase, bio- } \\
\text { tite and muscovite. }\end{array}$ & 7.1 & 7.2 & 7.7 & .0026 \\
\hline 28 & Woodbury, Vt & Biotite granite ........... & Coarse ............ & $\begin{array}{l}\text { Microcline and orthoclase, } \\
\text { quartz, oligoclase, biotite } \\
\text { and muscovite. }\end{array}$ & 6.1 & 6.2 & 6.6 & .0012 \\
\hline 30 & Windsor, $\mathrm{Vt}$ & $\begin{array}{l}\text { Hornblende biotite } \\
\text { granite. }\end{array}$ & Fine to medium & $\begin{array}{l}\text { Orthoclase, smoky quartz, } \\
\text { plagioclase (oligoclase-albite) } \\
\text { hornblende and biotite. }\end{array}$ & 5.3 & 5.6 & 5. 6 & .0038 \\
\hline 33 & Quincy, Mass ........... & Riebeckite-aegirite granite. & Coarse ............ & $\begin{array}{l}\text { Orthoclase, smoky quartz, } \\
\text { riebeckite, aegirite and albite. }\end{array}$ & 5.3 & 5.3 & 5. 9 & .0098 \\
\hline 37 & W. Chelmsford, Mass _. & $\begin{array}{l}\text { Muscovite-biotite } \\
\text { granite-gneiss. }\end{array}$ & Medium . & $\begin{array}{l}\text { Microcline and orthoclase, } \\
\text { oligoclase, quartz, rutile, } \\
\text { muscovite and biotite. }\end{array}$ & 5.5 & 5.6 & 6. 2 & .0032 \\
\hline 39 & Chester, Mass _... & $\begin{array}{l}\text { Biotite-muscovite } \\
\text { granite-gneiss. }\end{array}$ & Medium to fine... & $\begin{array}{l}\text { Microcline, quartz, plagioclase, } \\
\text { biotite and muscovite. }\end{array}$ & 6.5 & 6.6 & 7. 2 & .0066 \\
\hline 40 & Milford, Mass ... & Biotite granite $\ldots . . . . . .$. & Coarse ... & $\begin{array}{l}\text { Microcline and orthoclase, } \\
\text { quartz, plagioclase (albite- } \\
\text { oligoclase), and biotite. }\end{array}$ & 5. 9 & 6.4 & 6. 6 & .0020 \\
\hline 41 & Rockport, Mass .... & Hornblende granite..... & $\ldots$ do ...... & $\begin{array}{l}\text { Orthoclase and microcline, } \\
\text { smoky quartz, hornblende, } \\
\text { and plagioclase (albite- } \\
\text { oligoclase). }\end{array}$ & 5.4 & 5.7 & 5. 9 & .0038 \\
\hline 43 & Ansonia, Conn $\ldots$ & $\begin{array}{l}\text { Muscovite-biotite } \\
\text { granite-gneiss. }\end{array}$ & Fine .. & $\begin{array}{l}\text { Microcline and orthoclase, } \\
\text { quartz oligoclase, muscovite } \\
\text { and biotite. }\end{array}$ & 7.5 & 7.5 & 8.0 & .0058 \\
\hline 45 & East Lyme, Conn_ & Quartz monzonite & .... do & $\begin{array}{l}\text { Quartz, oligoclase, microcline } \\
\text { and orthoclase, biotite and } \\
\text { muscovite. }\end{array}$ & 7.0 & 7.1 & 7.5 & .0050 \\
\hline
\end{tabular}

See footnotes at end of table. 
TABLE 2. Description, source, classification, texture, composition, thermal expansion coefficients, and moisture expansion percentages of all samples tested-Continued

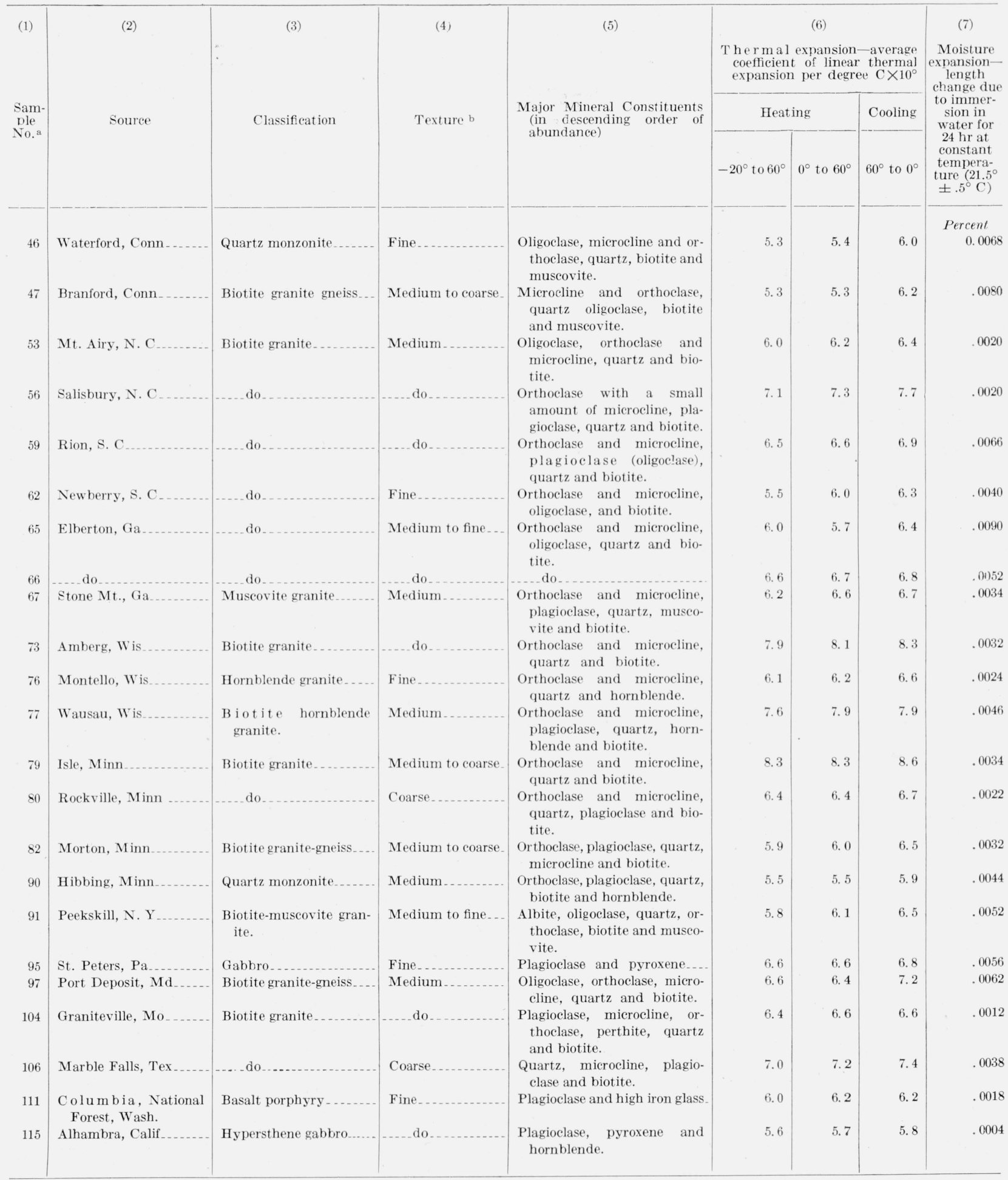

a Sample numbers correspond to the serial numbers listed in table 1 of R P1320 Journal of Research NBS 25, 161 (1940) RP1320.

b Texture refers to the average size of the feldspar grains, according to the following designation: fine, less than $0.5 \mathrm{~cm}$; medium, 0.5 to $1 \mathrm{~cm}$; coarse, slightly larger than $1 \mathrm{~cm}$. 


\section{Test Method for Thermal Expansion Measurements}

\section{Apparatus}

(a) Differential Interferometer

When the usual interferometer method is applied to measure the expansion of fine grained materials, a relatively small specimen, 2 to $6 \mathrm{~mm}$ in height is generally used [17]. However, in order to make the interferometer applicable to the thermal expansion measurement of medium and coarse grained granites it was found necessary to use a test specimen considerably larger than the conventional small one.

For this purpose, a differential interferometer, similar to that applied by Saunders [18], was used to make the expansion measurements. This method is a modification of Fizeau's differential interferometer [19] in which the three adjustable screws used by Fizeau to support the top plate were replaced by a perforated fused quartz tube of a specific height.

In these tests the specimen is $38.42 \mathrm{~mm}$ high (avg. size), T-shaped in cross section, and with a maximum width and depth of $12.5 \mathrm{~mm}$. The sides are perforated to reduce its heat capacity to a minimum. Figure 1 is a schematic diagram of the interferometer arrangement used in all tests. The specimen rests on a glass thermometer plate, $e$, and supports an interferometer plate, $b$,

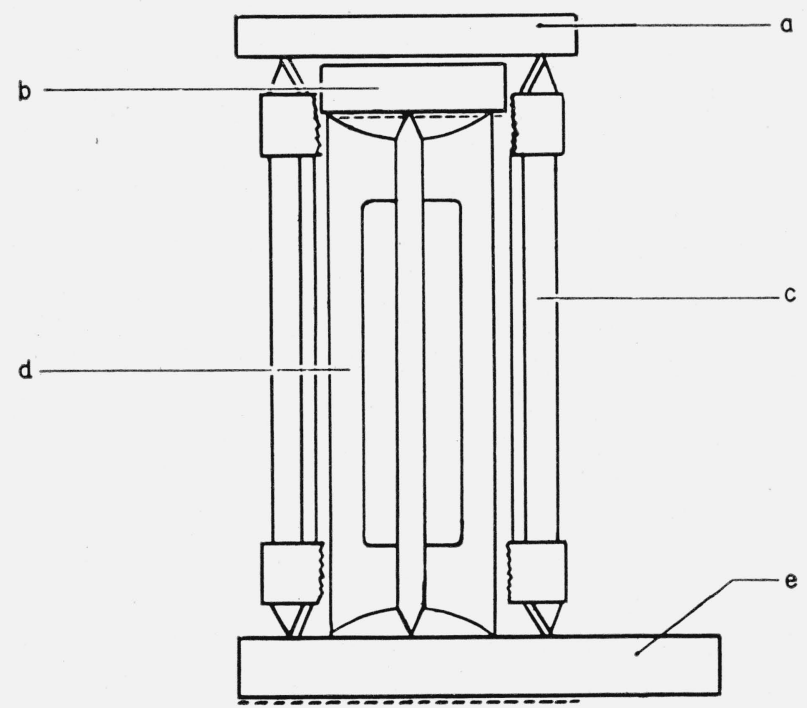

Figure 1. Diagram of differential interferometer.

a, Top interferometer plate; b, lower inteferometer plate; c, fused quartz tube supporting top plate; $d$, test specimen; e, thermometer plate. on its upper surface. Another interferometer plate, $a$, is supported approximately $0.5 \cdot \mathrm{mm}$ above plate $b$ by a perforated fused quartz tube $42.65 \mathrm{~mm}$ high, the latter also resting on plate $e$ and surrounding the specimen, $d$. Plate $a$ is polished on both faces. Plates $b$ and $e$ are polished on the upper faces and fine ground on the lower, with the exception of a small area on plate $e$, which is polished on both faces in order to produce the temperature fringes. The expansion of the specimen on heating causes plate $b$ to move toward plate $a$. This results in a movement of the interference fringes in the field. (See section IV -6 for the details of calculations.)

\section{(b) Thermal Chamber}

The thermal chamber (fig. 2) was the same as that used by Johnson and Parsons [9]. A brass cylinder, 9 in. long and 3 in. in diameter was inserted through the top of an ordinary electric refrigerator into a tank of kerosine, which surrounded the freezing coils. The heating element consisted of a hard rubber tube wound with 30 $\mathrm{ft}$ of No. 24 Nichrome wire. A removable copper cup, supported from the refrigerator top by steel rods, held all the components of the interferometer. Just beneath the bottom thermometer plate were inserted the three variable junctions of a copper-constantan thermocouple. Three slide wire resistors, an ammeter, and a toggle switch were placed in series with the heating element and the $110-\mathrm{v}$ power source for control of the heating current.

\section{(c) Recording Mechanism}

A recording apparatus (fig. 2) previously constructed and used by Johnson and Parsons [9], was a simplified form of the one originally designed by Saunders [20]. This apparatus replaced the eyepiece of the ordinary Pulfrich type interferometer viewing instrument and thus eliminated the tedious job of counting fringes visually. A strip of $35-\mathrm{mm}$ high speed photographic film was drawn from an ordinary camera cartridge over rollers by a sprocket geared to a synchronous motor, at the rate of $1 \frac{1}{2} \mathrm{in}$. per hr. A lens focused the interference pattern through a yellow filter upon a screen with a slit $1 / 4 \mathrm{~mm}$ wide, which allowed only a very narrow portion of the image to reach the slowly moving film. A side tube with a slotted mirror placed at a $45^{\circ}$ angle, permitted 

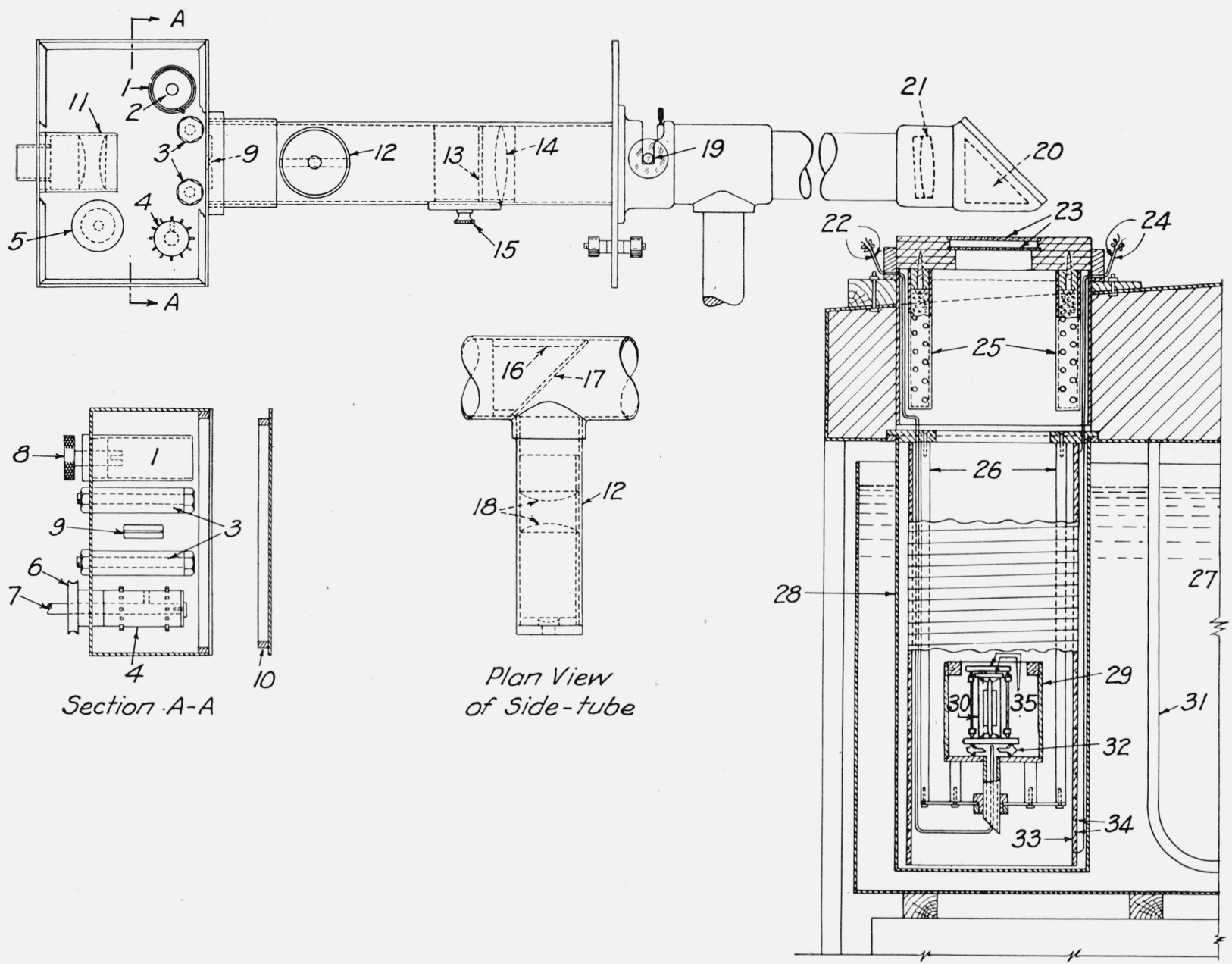

Figure 2. Diagram of viewing instrument, recording camera, and thermal chamber.

1, Magazine; 2, film cartridge; 3, film rollers; 4, feed sprocket; 5, take-up spool; 6, pulley to take-up spool; 7, drive shaft geared to synchronous motor; 8, rewind knob; 9, slit (aperture); 10, light-tight cover; 11, camera eyepiece and lenses; 12, side-tube eyepiece; 13, yellow filter; 14, objective lens; 15, focus adjustment; 16, mirror support; 17, mirror; 18, side-tube eyepiece lenses; 19 , spectrum tube; $20,90^{\circ}$ prism; 21 , objective; 22 , heating coil terminals; 23 , double glass; 24, thermocouple leads; 25, dessicant tubes; 26, steel supports; 27, kerosine: 28, brass cylinder; 29, copper cup; 30, specimen; 31, refrigerator cooling coil; 32 , glass ring; 33 , hard rubber tube; 34 , nichrome wire; 35 , interferometer plates.

visual observations for checking purposes during the operation of the recorder (see reference [20] for details of the recording instrument).

\section{Temperature Determinations}

Temperatures were measured with an optically ground thermometer plate (fig. 1, e) often referred to as an interference or refraction thermometer [21]. This plate gave a satisfactory set of straight interference bands that shifted at a definite rate whenever it was heated or cooled. In order to calibrate this thermometer plate it was placed, together with the other components of the interferometer, into the thermal chamber, and a thermometer fringe count determined for a number of equilibrium temperatures, the latter being measured by a three-junction thermocouple located just beneath the plate. The fringe numbers obtained in this manner were plotted against the temperatures, and a fringe-temperature curve drawn. From this curve it was possible to determine the temperature corresponding to any specifically numbered fringe. During each test the temperature fringes were recorded simultaneously with the expansion fringes.

\section{Preparation of the Specimens}

Figure 3, a, b, c and d illustrates the stages in the fabrication of a typical test specimen. A rectangular prism, approximately $12.5 \mathrm{~mm}$ by 
$12.5 \mathrm{~mm}$ in cross section and approximately 38.5 $\mathrm{mm}$ in length was first cut from the granite sample by means of a 6 -in. circular diamond saw. Sections were then cut away with the same saw leaving a $T$-shaped piece having sides approximately $2.5 \mathrm{~mm}$ thick (fig. 3, b and c). Next, with the aid of small fine silicon carbide grinding wheels, the specimen illustrated in figure 3, d was completed. The ends of the finished specimen were ground so that there were three polished points at the bottom to contact the glass thermometer plate, and three points at the top to support the lower interferometer plate. Similarly, the quartz tube used to support the upper interferometer plate (fig. 1) had three polished points on its top and bottom surface.

With a fine emery stone and a micrometer gage the heights of the "legs" of the specimen were equalized to within $0.005 \mathrm{~mm}$. The legs of the quartz supporting tube were adjusted to a height of $42.65 \mathrm{~mm}$. By setting up all the various parts of the interferometer and examining through a viewing instrument, the heights of the legs of the specimens were adjusted further to give the desired interference pattern. The finished specimens, which averaged $3.2 \mathrm{~g}$ in weight, were dried at $80^{\circ} \mathrm{C}$ for 4 days and placed in a desiccator until ready for test.

\section{Test Procedure}

After the desired fringe pattern was obtained, the copper cup containing all the components of

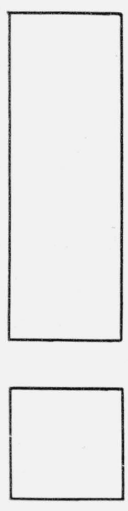

a

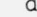

Figure 3.
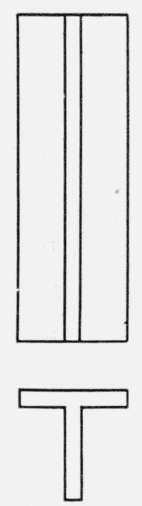

b
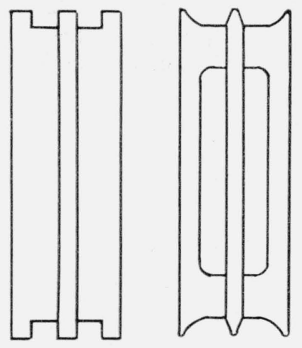

FRONT

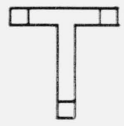

c

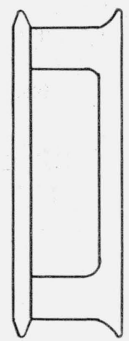

SIDE the interferometer was placed, very carefully, into the thermal chamber. The chamber was closed, and after a preliminary fast heating to $68^{\circ} \mathrm{C}$ to stabilize the air films between the points of contact of the specimen and of the quartz tube with the interferometer plates [22], the cooling system was started and allowed to operate overnight. Next morning after the final adjustments were made on the viewing instrument and recording apparatus, the film was inserted, and the initial temperature determined by the thermocouple. The recorder was then started, cooling system turned off, the heating current turned on and increased at 15min intervals to produce a uniform rise in temperature of approximately $0.4^{\circ} \mathrm{C}$ per minute. When the final temperature was reached (approximately $65^{\circ} \mathrm{C}$ ), the cooling system was again turned on, and the heating current reduced at regular intervals until the temperature fell just below $0^{\circ} \mathrm{C}$. The recorder was then stopped, the chamber reheated to room temperature to prevent condensation inside, and the specimen removed. Finally the film was rewound into the cartridge and removed for development.

\section{Description of the Interferogram}

The interference pattern when seen through the viewing instrument appears as shown in figure 4, A. When the eyepiece of the instrument is replaced with the recording apparatus, only a narrow portion of the pattern is focused on the moving film (fig. 4, B). Figure 4, C and D are schematic drawings of portions of a typical interferogram resulting from the fringe pattern shown in figure $4, \mathrm{~A}$ and $\mathrm{B} .{ }^{3}$ The fringes become a series of bands that are parallel to the direction of the movement of the film only so long as thermal equilibrium is maintained, such as during the first few minutes of a test. The upper portion of figure 4, C illustrates this condition. When the temperature begins to rise and the specimen expands, there is a corresponding movement of temperature and expansion fringes. To prepare the interferogram for the counting of fringes, penciled lines are drawn parallel to a slit line ${ }^{4}$ through each intersection of an even numbered thermometer fringe with the thermometer reference line. Where each of these penciled lines crosses

\footnotetext{
3 Expansion data were read from a $3 \times$ enlargement of the interferogram.

${ }^{4} \mathrm{~A}$ slit line is produced on a film by turning off the source of monochromatic light for about 30 sec during a test, resulting in a narrow underexposed strip.
} 


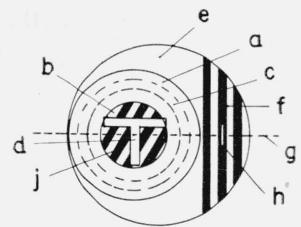

A

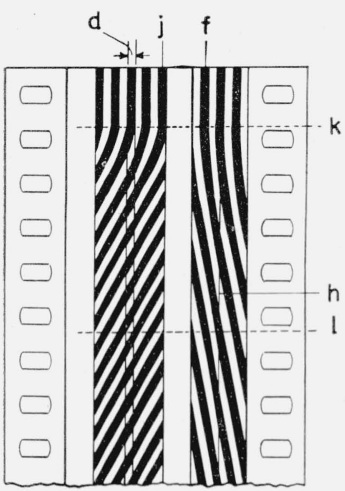

C

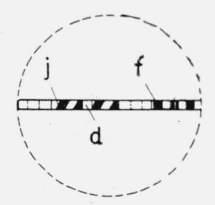

B

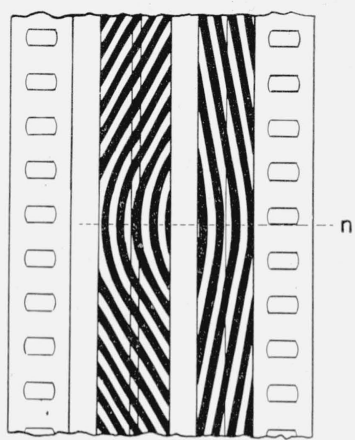

D
FiguRE 4. Interferometer and interferogram.

A, Interferometer as seen through the viewing instrument; B, exposure slit magnified to show fringes; $C$, section of interferogram at start of test; $D$, middle section of interferogram: a, top interferometer plate; $b$, lower interferometer plate; c, fused quartz tube; $d$, test specimen; e, thermometer plate; $\mathrm{f}$, temperature fringe; $\mathrm{g}$, position of exposing slit in camera; $\mathrm{h}$, thermometer reference mark; $j$, expansion fringe; $k$, point where fringes begin to move; 1 , line (parallel to slit line) drawn through intersection of thermometer fringe No. 4 and expansion fringe No. 6.5; $\mathrm{n}$, maximum temperature and reversal ef fringes.

the middle of the specimen trace, the simultaneous expansion fringe number is noted. For example, line $k$ passes through temperature fringe No. 0 and expansion fringe No. 0 , line $l$ passes through temperature fringe No. 2 and expansion fringe No. 6.5.

Fringe data for a typical test were as follows:

\begin{tabular}{|c|c|c|}
\hline $\begin{array}{l}\text { Temperature } \\
\text { fringe No. }\end{array}$ & Temperature & $\begin{array}{l}\text { Expansion } \\
\text { fringe No. }\end{array}$ \\
\hline $\begin{array}{r}0 \\
2 \\
4 \\
6 \\
8 \\
10 \\
12 \\
14 \\
16\end{array}$ & $\begin{array}{c}{ }^{\circ} C \\
-22.2 \\
-10.6 \\
+0.6 \\
11.6 \\
22.1 \\
32.4 \\
42.2 \\
51.8 \\
61.0\end{array}$ & $\begin{array}{c}0 \\
6.9 \\
11.5 \\
15.5 \\
21.0 \\
27.0 \\
33.8 \\
41.0 \\
49.3\end{array}$ \\
\hline
\end{tabular}

When the maximum temperature was reached and cooling began, the direction of the fringe movement for both expansion and temperature was reversed (figure $4, \mathrm{D}, n)$. As the fringes recrossed their respective reference marks they were assigned their previous numbers.

\section{Calculation of Results}

Since the total number of expansion fringes passing during a test was affected by the expansion of the quartz tube and the interferometer plate, $b$, as well as that of the granite specimen (fig. 1), it was necessary to develop a formula that would include all these factors. The following formula was used for this purpose:

$\Delta L=\frac{\left.N \frac{\lambda}{2}-C \cdot S \times 10^{-4}+\left[\left(A_{q} \cdot L_{q}\right)-A_{v} \cdot L_{v}\right)\right]\left(T_{2}-T_{1}\right)}{L}$

where $L=$ length of specimen at initial temperature $T_{1}$ in millimeters;

$\Delta L=$ linear expansion of specimen in $\mathrm{mm} / \mathrm{mm}$ from $\mathrm{T}_{1}$ to any higher temperature, $T_{2}$;

$N=$ number of observed fringes;

$\lambda=$ wavelength of monochromatic light in millimeters;

$C=$ air correction in microns per centimeter. ${ }^{5}$

$S=$ air space between interferometer plates $a$ and $b$ in millimeters;

$A_{q}=$ expansion coefficient of fused quartz tube per deg $\mathrm{C}$ from $T_{1}$ to $T_{2} ;{ }^{6}$

$L_{q}=$ length of fused quartz tube at $T_{1}$ in millimeters;

$A_{v}=$ expansion coefficient of interferometer plate $b$ per deg $\mathrm{C}$ from $T_{1}$ to $T_{2} ;{ }^{6}$

$L_{v}=$ height of interferometer plate $b$ at $T_{1}$ in millimeters.

\section{Reliability of Results}

In order to check the performance of the apparatus, samples of three different materials, namely, porcelain, glass, and a metal alloy were tested for thermal expansion. These values were compared with those obtained on identical ma-

\footnotetext{
5 Data taken from the table of air corrections listed in reference [17].

${ }^{6}$ Expansion coefficient of the fused quartz was determined by the usual interferometer method on a small sample cut from the original piece of quartz tubing. The expansion coefficient of the interferometer plate $b$ (Vycor brand glass) was taken from reference [18]
} 


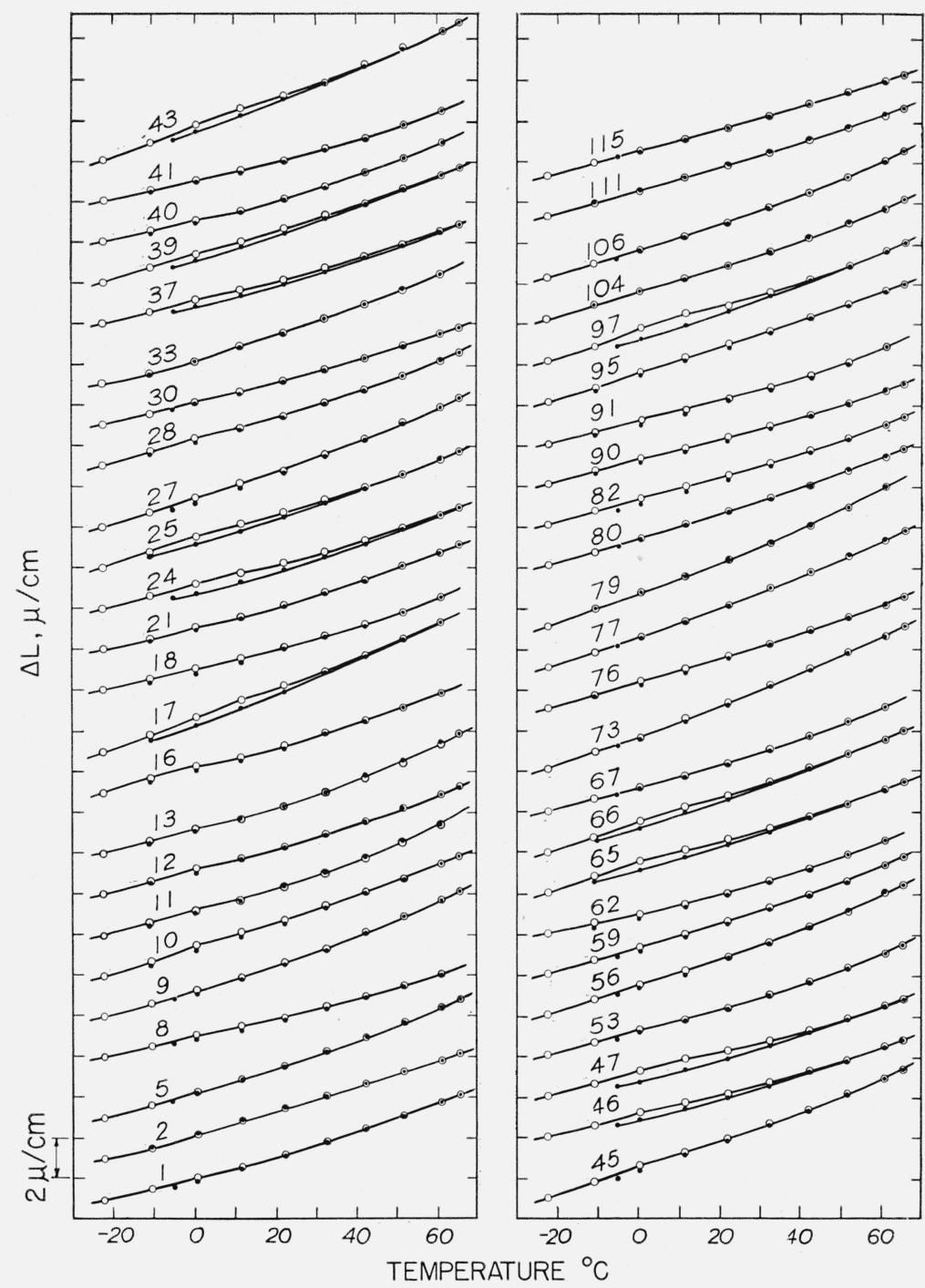

Figure 5. Thermal expansion curves of 48 samples of granite.

cooling points; figures refer to sample numbers in table 2.

terials by the Thermal Expansion Section of this Bureau. The results were as follows:

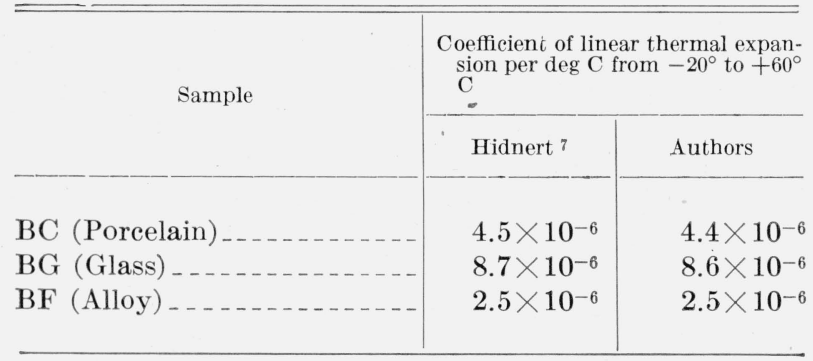

${ }^{7}$ Chief, Thermal Expansion Section, National Bureau of Standards.

The results agree within the limits of experimental error.

\section{Thermal Expansion Results and Discussion}

\section{General}

Table 2, column 6 gives the mean coefficients of linear thermal expansion for three different temperature ranges of all samples tested, and figure 5 shows their characteristic heating and cooling curves. The coefficients obtained for the 48 samples ranged from 4.8 to $8.3 \times 10^{-6}$ per deg $\mathrm{C}$ between $-20^{\circ}$ and $+60^{\circ} \mathrm{C}$ with an average of $6.2 \times 10^{-6}$. The coefficients of 84 percent of the samples in this same temperature range were between 5 and $7 \times 10^{-6}$ per deg C. For the 
temperature range $0^{\circ}$ to $60^{\circ} \mathrm{C}$, the average of the coefficients was $6.3 \times 10^{-6}$ and on cooling $\left(60^{\circ}\right.$ to $0^{\circ} \mathrm{C}$ ), it was $6.7 \times 10^{-6}$ per $\operatorname{deg} \mathrm{C}$.

\section{Irregularity of Expansion}

A general view of all the expansion curves as illustrated in figure 5 reveals more or less smooth regular curves on both heating and cooling. However, on closer scrutiny it can be readily seen that at least 65 percent of the samples expand at a certain rate until the region of 0 to $10 \mathrm{deg}$ is reached, then change to a slower rate for about 10 deg and finally resume a new rate of expansion that continues regularly until the maximum temperature is reached. On the other hand, the cooling curves of all the samples show little evidence of irregularities. Samples 17, 24, 46, 47, 65 , and 97 show some of the more pronounced instances of irregular heating curves. These irregularities were reproducible on retesting of the samples.

The irregular expansion appears to be due to moisture changes in the sample during the test. If water is prevented from entering the sample during a test the irregularities disappear. Three samples showing irregular expansions were retested after having been dried at $80^{\circ} \mathrm{C}$ for 4 days and coated with a synthetic resin water-proofing. The resulting curves (fig. 6) showed virtually no irregularities after the treatment. It might also be noted here that the testing of nonabsorptive materials, such as glass and metal, produced smooth coinciding curves on both heating and cooling.

Since the uncoated samples were dry at the start of each test, absorption of moisture by them is likely during the tests. As the temperature of the surrounding atmosphere is reducat, the relative humidity rises and although the outer wall of the chamber is colder than the sample during the initial cooling part of the cycle, the latter's very dry initial condition might make it receptive to atmospheric moisture. During the early heating part of the cycle the sample is colder than its surroundings, hence condensation of moisture on it might be expected. A portion of this moisture would most certainly be absorbed. Further heating would raise the vapor pressure of the water in the sample above that of the surrounding atmosphere and produce a drying action.

As shown in section VII, granites expand when moisture is absorbed. Absorption of water during the early heating part of the cycle might account for the increased slope of the expansion curve in that range, while loss of moisture at higher temperatures is consistent with the reduced rate of expansion occurring at about $10^{\circ} \mathrm{C}$.

The abrupt change in slope observed in some of the curves at $0^{\circ} \mathrm{C}$ or slightly above might indicate that some of the absorbed moisture was in a frozen state below that temperature. If the sample absorbs water while being cooled to $-20^{\circ}$ $\mathrm{C}$, there is ample opportunity for the water to become frozen since the sample is maintained at this low temperature for at least $9 \mathrm{hrs}$. The relative high thermal coefficient of ice might contribute to the over-all expansion at the lower temperatures, while a gradual melting with attendant loss in volume would reduce the observed slope on further heating.

Further evidence to show that irregularities are

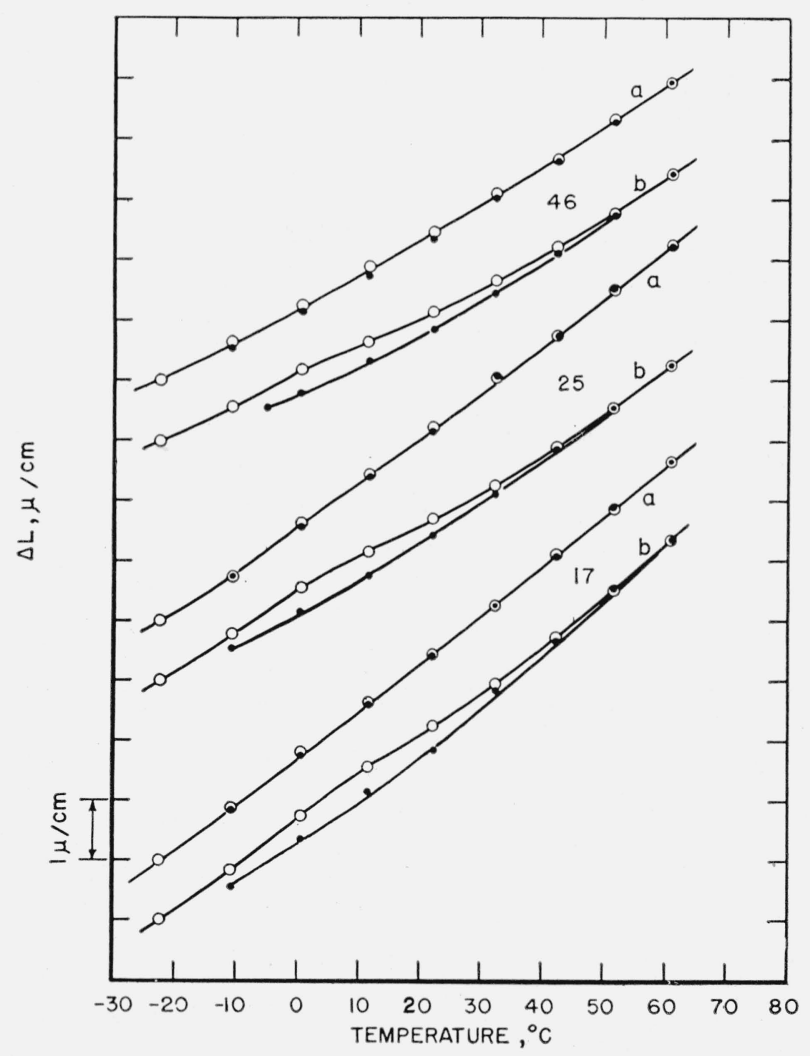

FIGURE 6. Thermal expansion curves for three samples of granite showing the effect of waterproofing the test specimens.

$\bigcirc$, Heating points; $\bullet$, cooling points; figures refer to sample numbers in table 2. a, waterproofed; $b$, original test. 
probably due to moisture in some form is indicated by the fact that six samples showing no irregularities had an average absorption value of 0.08 percent $^{8}$ and a moisture expansion value of 0.0026 percent. On the other hand, the six samples showing the most pronounced irregularities had an average absorption value of 0.25 percent and a moisture expansion value of 0.0072 percent. The average absorption and moisture expansion values for all samples were 0.20 percent and 0.0039 percent, respectively.

\section{Effect of Mineral Composition}

The thermal expansivity of granite is a function of the expansivities of its mineral constituents. There are some data available on the thermal expansion coefficients of the chief minerals in granite. The values in table 3 indicate that the expansion coefficients of quartz differ from those of the feldspars, and that the coefficients of potash feldspar are different from those of the soda-lime

TABLE 3. Mean coefficients of linear thermal expansion for some oriented minerals contained in granite

\begin{tabular}{|c|c|c|c|c|}
\hline \multirow[t]{2}{*}{ Mineral } & \multirow[t]{2}{*}{ Orientation } & \multicolumn{2}{|c|}{$\begin{array}{l}\text { Mean coefficient } \\
\text { of linear ther- } \\
\text { mal expansion } \\
\text { per degree } \\
\mathrm{C} \times 10^{6}\end{array}$} & \multirow[t]{2}{*}{ Source } \\
\hline & & $\begin{array}{l}-20^{\circ} \text { to } \\
+60^{\circ}\end{array}$ & $\begin{array}{c}+60^{\circ} \text { to } \\
0^{\circ}\end{array}$ & \\
\hline Quartz ...... & Perpendicular to $c$-axis & 13.5 & 13.5 & $\begin{array}{l}\text { Johnson \& Par- } \\
\text { sons [9]. }\end{array}$ \\
\hline Do & Parallel to $c$-axis $\ldots$ & 7.4 & 7.7 & Do. \\
\hline Microcline ... & Parallel to $b$-axis $\ldots . . .$. & 1.1 & 1.3 & Do. \\
\hline Do $\ldots . . . .$. & Perpendicular to $b$-axis & 3.5 & 3.2 & Do. \\
\hline Do & Parallel to $a$-axis $\ldots . . .$. & 17.1 & 17.3 & Do. \\
\hline \multirow[t]{2}{*}{ Oligoclase } & _._. do & 3.1 & 3.7 & Do. \\
\hline & & \multicolumn{2}{|c|}{$20^{\circ}$ to $100^{\circ}$} & \\
\hline Orthoclase .. & _.... do ... & \multicolumn{2}{|c|}{15.0} & $\begin{array}{l}\text { Kozu and Saiki } \\
\text { [23]. }\end{array}$ \\
\hline $\begin{array}{r}\text { Do_...... } \\
\text { Plagioclase }\end{array}$ & $\begin{array}{l}\text { Parallel to } b \text {-axis } \\
\text { Parallel to } a \text {-axis }\end{array}$ & 0.0 & 11.2 & $\begin{array}{l}\text { Do. } \\
\text { Kozu and Ueda }\end{array}$ \\
\hline Do . & Perpendicular to $010 \ldots$ & \multicolumn{2}{|c|}{3.8} & $\begin{array}{l}{[24] .} \\
\text { Do. }\end{array}$ \\
\hline Hornblende .. & Perpendicular to $100 \ldots$ & \multicolumn{2}{|c|}{6.2} & Do. \\
\hline Do & Parallel to $b$ & \multicolumn{2}{|c|}{7.5} & Do. \\
\hline Do $\ldots \ldots$ & Parallel to $c$ & \multicolumn{2}{|c|}{$\begin{array}{l}7.2 \\
5.0\end{array}$} & Di. \\
\hline Olivine ... & Parallel to $a_{\ldots} \ldots \ldots$ & & 0 & $\begin{array}{c}\text { Kozu, Ueda \& } \\
\text { Tsumori [25]. }\end{array}$ \\
\hline Do & Parallel to $b$ & \multirow{2}{*}{\multicolumn{2}{|c|}{$\begin{array}{r}10.0 \\
8.8\end{array}$}} & Do. \\
\hline Do $\ldots . . . . .$. & Parallel to $c$ & & & Do. \\
\hline
\end{tabular}

8 Absorption values were determined by measuring the percentage gain in weight of cylindrical specimens, 2 in. in diameter and $2 \frac{1}{2}$ in. long, after 48 $\mathrm{hr}$ immersion in water at room temperature. Moisture expansion tests are described in section VII. feldspars. Furthermore, each mineral expands at different rates along different crystallographic axes. Since a typical granite of this investigation contains four major mineral constituents plus several minor ones, all occurring in random orientation, it would seem impossible to form a precise correlation between mineral constituents and expansivity. Granites of similar mineral composition but from different quarries gave different results.

Potash feldspar was the most abundant mineral constituent in 35 of the 48 samples tested. The average of the thermal coefficients obtained for these 35 samples was $6.2 \times 10^{-6}$ per deg $\mathrm{C}$ between $-20^{\circ}$ and $+60^{\circ} \mathrm{C}$. For the 10 samples containing soda-lime feldspar as the most abundant mineral constituent, the average of the coefficients was $6.3 \times 10^{-6}$ per $\operatorname{deg} \mathrm{C}$ in this same range.

Quartz was the most abundant mineral constituent in 3 of the 48 samples tested. The average of the coefficients for these samples was $7.0 \times 10^{-6} /$ deg $\mathrm{C}$ between $-20^{\circ}$ and $+60^{\circ} \mathrm{C}$. Since the average of the coefficients of quartz measured in all directions is higher than those of the feldspars, it seems logical that samples with an abundance of quartz would have higher than average coefficients.

\section{Thermal Expansion Data for Other Building Stones}

Table 4 shows the range in linear thermal expansion coefficients determined for some other types of stone used for structural purposes.

\section{Test Method for Moisture Expansion \\ 1. Specimens}

For convenience in preparation, cylindrical specimens, 2 in. in diameter and $2 \frac{1}{2} \mathrm{in}$. long, were cored from the original granite samples. Two plane surfaces opposite each other were ground on each specimen, one to provide a base and the other for attachment of the gage.

\section{Apparatus}

A brass tank large enough to accommodate two specimens was enclosed within a well insulated box with a cover having three holes. Two of the holes were so spaced as to provide openings for reading the gages, and the other was fitted with a 2-hole rubber stopper for a thermometer 
TABLE 4.-Mean coefficients of linear thermal expansion for some building stones other than granite

\begin{tabular}{|c|c|c|c|c|}
\hline \multirow[t]{2}{*}{ Material } & \multirow[t]{2}{*}{ Source } & \multirow[t]{2}{*}{ Orientation } & \multicolumn{2}{|c|}{$\begin{array}{l}\text { Mean coefficient } \\
\text { of linear } \\
\text { thermal expan- } \\
\text { sion per degree } \\
\mathrm{C} \times 10^{6}\end{array}$} \\
\hline & & & $\begin{array}{l}-20^{\circ} \text { to } \\
+60^{\circ}\end{array}$ & $\begin{array}{c}+60^{\circ} \\
0^{\circ}\end{array}$ \\
\hline Limestone. . & Rockwood, Ala.... & $\begin{array}{l}\text { Parallel to bedding } \\
\text { plane. }\end{array}$ & 0.7 & -0.1 \\
\hline Do_. & ...... do ... & $\begin{array}{l}\text { Perpendicular to bed- } \\
\text { ding plane. }\end{array}$ & 1. 7 & 2. 9 \\
\hline Do $\ldots . . . .$. & Bedford, Ind. & $\begin{array}{l}\text { Parallel to bedding } \\
\text { plane. }\end{array}$ & 2.8 & 3.4 \\
\hline Do_.. & $\ldots$..... do . . & $\begin{array}{l}\text { Perpendicular to bed- } \\
\text { ding plane. }\end{array}$ & 4.2 & 4. 2 \\
\hline Marble..... & South Dover, N. Y. & $\begin{array}{l}\text { "A" direction (ran- } \\
\text { dom). }\end{array}$ & 8.7 & 9.2 \\
\hline Do.. & ..... do & $\begin{array}{l}\text { Perpendicular to " } A \text { " } \\
\text { direction. }\end{array}$ & 5. 2 & 5. 9 \\
\hline Sandstone _. & MeDermott, Ohio .. & $\begin{array}{l}\text { Parallel to bedding } \\
\text { plane. }\end{array}$ & 9.2 & 10.2 \\
\hline Do $\ldots$ & ..... do . . & $\begin{array}{l}\text { Perpendicular to bed- } \\
\text { ding plane. }\end{array}$ & 9.5 & 10.5 \\
\hline
\end{tabular}

and funnel. Two calibrated Tuckerman optical strain gages [26], of 2-in. gage length, reading to $2 \times 10^{-6}$ in. were used for the expansion measurements (fig. 7). The knife edges of the gages were mounted on thin brass strips attached to the specimen with water-proof cement.

\section{Procedure}

The specimens were dried at $105^{\circ} \mathrm{C}$ for $24 \mathrm{hr}$ and cooled in a desiccator. The brass strips were then attached to one plane face of each specimen and, when the cement had hardened

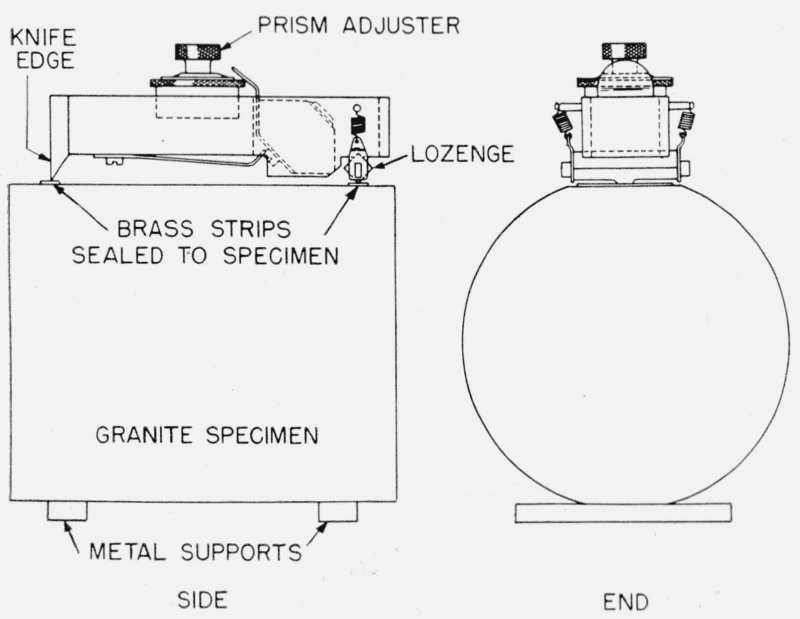

Figure 7. Diagram of Tuckerman optical strain gage mounted on granite specimen. sufficiently, the specimens were taken into a controlled temperature room. The gages were then mounted and the knife edges held in firm contact with the metal strips by small rubber bands placed around the specimens and gages. The specimens with the gages were then placed in the brass tank and left overnight to reach an equilibrium temperature (about $21^{\circ} \mathrm{C}$ ). A flask of distilled water was also left standing near the specimens. About $16 \mathrm{hrs}$ later the gages were read and water poured into the tank until the level reached the tops of the specimens. Gage readings were taken at approximately 1 -hr intervals for $8 \mathrm{hrs}$ and a final reading after $24 \mathrm{hrs}$.

During any test, the temperature of the water did not vary more than $\pm 0.5 \mathrm{deg} C$. The maximum difference in temperature of the water between the time of the first and last reading was $0.2 \mathrm{deg}$ C. Errors due to thermal expansion of the gage or specimen were thereby virtually eliminated.

To verify the fact that the length changes observed in the stone specimens were caused only by the absorption of water, two metal cylindrical specimens were tested in the manner described. The greatest change observed in four tests was $2 \times 10^{-6} \mathrm{in}$. Since the gages are sensitive only to this amount, it can be assumed that no significant dimensional change took place during these tests.

\section{Moisture Expansion Results}

Table 2, column 7 , gives the linear moisture expansion results for the 48 samples of granite. The values range from a minimum of 0.0004 percent to a maximum of 0.0090 percent, with an average of 0.0039 percent. Although the immersion period for each test was $24 \mathrm{hrs}$, five specimens exhibited maximum expansion in $1 \mathrm{hr}$, and 28 specimens between 2 and $8 \mathrm{hrs}$.

Figure 8 gives moisture expansion curves for nine samples, together with the corresponding absorption curves. These show results typical for all samples tested. Both the expansion and absorption curves tend to rise sharply during the first few hours and then quickly level off, but there seems to be little correlation between the amounts of expansion and absorption. The moisture expansion values were also compared with density, porosity, and mineral composition but no correlation was found with these properties. 


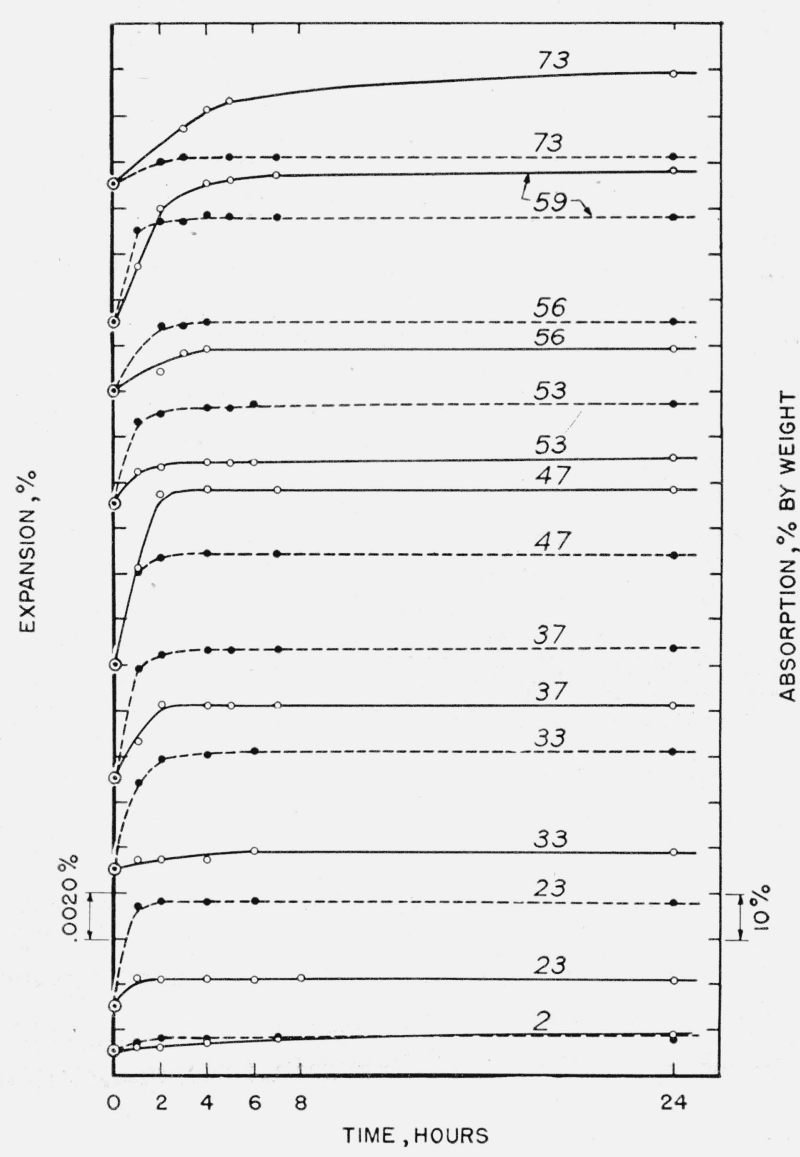

Figure 8. Moisture expansion and corresponding absorption curves of nine granite samples.

$\checkmark$, Moisture expansion points; - absorption points; figures refer to sample numbers in table 2 .

Table 5 shows the moisture expansion values obtained for several samples of other types of building stone, tested in the manner described.

\section{Thermal and Moisture Expansion in Relation to Durability of Granite}

Merrill [27] cites several cases of rock weathering, including granite, which he attributed to heating and cooling effects. Temperature changes can produce internal stresses in two ways: (1) a thermal gradient due to heating or cooling of one surface causes unequal expansion of layers at different depths; (2) the various mineral constituents of granite have different expansion rates among themselves and also in different crystallographic directions. Stresses caused by both conditions come into action simultaneously and augment each other. Although such stresses are
TARLE 5. Moisture expansion values of some building stones other than granite

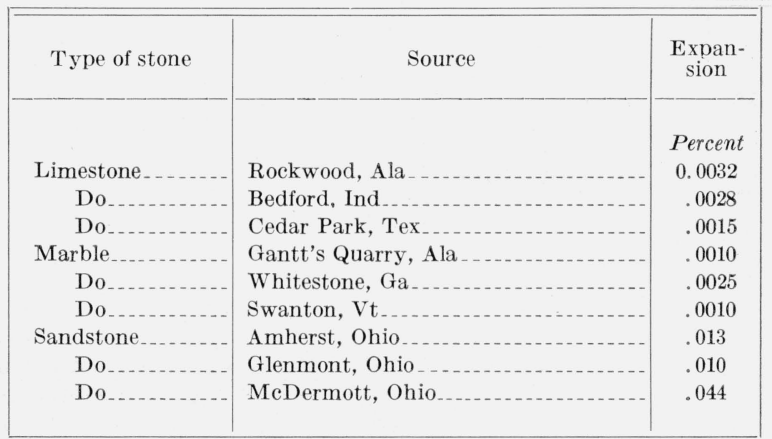

usually much lower than those required to produce rupture, frequent repetition and reversal of directions may ultimately cause fractures. These stresses in a compact material like granite are probably greater than in more porous materials.

Two cases can be cited in which rather large spalls occurred at corners of granite masonry where the superimposed loads were not sufficient to account for the fractures. It seems possible that a complication of stresses due to temperature effects might occur in such parts of structures.

One case of cracking has been examined where the facade of a building is made of a granite with unusually large quartz crystals. The polished columns show considerable cracking on the parts most exposed to the sun, while the shaded parts appear to be entirely sound. Several cubic inches of granite have crumbled away from the corner of a column base that is freely exposed to the afternoon sun. This case provides evidence that unequal expansion of the minerals might be causing the deterioration.

The moisture expansion values obtained in this study of granites are not large in comparison with values obtained on certain other types of building materials. In general the total expansion of granites due to moisture (using average values) is equivalent to the thermal expansion produced by a temperature change of about $6 \mathrm{deg} \mathbf{C}$. It was not possible to determine by the methods used in this study if a wet specimen expands at the same rate, due to a thermal change, as a dry specimen. It can be assumed that the two types of expansion occur simultaneously, and the total expansion of a wet granite can be computed as the sum of the moisture and thermal changes. Using the average values for the thermal and moisture expan- 
sions, it is found that a $100-\mathrm{ft}$ course of granite may expand 0.05 in. on becoming wet and 0.08 in. due to a $10 \mathrm{deg} \mathrm{C}$ increase in temperature, giving a total of 0.13 in. If the course is constrained, there will be an elastic deformation of 0.13 in., and one may estimate the stress produced where the modulus of elasticity ( $E$ value) is known. Assuming an $E$ value of $7,000,000$ $\mathrm{lb} /$ in. $^{2}$, the resulting compressive stresses would be $760 \mathrm{lb} /$ in. $^{2}$, which is high in comparison with the superimposed weight stresses in most structures, but rather low in comparison with strength of granite.

A more serious effect might result on coping courses where the masonry has more freedom of movement. The combined effect of thermal and moisture expansion may cause each block to move toward the ends of the structure; but when contraction occurs, there is insufficient tensile strength in the mortar joints to pull the blocks back to their original position, hence cracks at the joints are produced. These cracks become partly filled with dirt and sand from the mortar and the next expansion results in moving the blocks still further. Open joints allow water to enter, and freezing may cause rupture of the mortar in joints at lower levels.

Schaffer [28] points out that a stress gradient is produced by moisture from rains because the stone is soaked to only a slight depth. He believes that frequent repetition of such stresses might produce injurious effects. Observation on granite buildings shows that the surface of granite often scales off, but the scaling is usually confined to small areas of the lower courses. This can be explained by the assumption that salts are carried up into the granite by ground water; and crystals are formed in the pores. The expansive action of the salt crystals in forming causes tensile stresses perpendicular to the exposed face in sufficient amounts to cause the flaking. It seems likely that a compressive stress parallel to the face resulting from a moisture gradient would aggravate the flaking action.

Based on such studies as have been made on structures, it is the authors' belief that most granites are not affected as seriously by thermal and moisture expansion as by other physical and chemical agencies. Deterioration due to expansion probably does not manifest itself appreciably during the normal life of a building, but it may become apparent on certain monumental structures after a long period of time.

\section{Summary}

1. Thermal and moisture expansion determinations were made on 48 samples of domestic granites representative of those used in important structures. Complete descriptions are given of the apparatus and test procedures used in making the measurements. The major mineral constituents of the samples were determined by petrographic methods.

2. The linear thermal expansion coefficients for all samples ranged from 4.8 to $8.3 \times 10^{-6}$ and averaged $6.2 \times 10^{-6}$ per $\operatorname{deg} \mathrm{C}$ for the range $-20^{\circ}$ to $+60^{\circ} \mathrm{C}\left(-4^{\circ}\right.$ to $\left.140^{\circ} \mathrm{F}\right)$. This average value is smaller than the average $\left(7.7 \times 10^{-6}\right)$ obtained by previous investigators, which may be accounted for in part by the lower temperature range explored in the present study. The coefificients of 84 percent of the samples were between 5 and $7 \times 10^{-6}$ per deg C.

3. Some irregularities in the heating curves were evident in about 65 percent of the samples tested. These irregularities, which occurred somewhere between $0^{\circ}$ and $+20^{\circ} \mathrm{C}$, were probably due to moisture changes in the sample during the test.

4. Although a definite correlation between thermal expansion and mineral composition could not be established from the values obtained because of the heterogeneous composition of granite, the results indicated that granites with exceptionally high percentages of quartz had higher than average coefficients.

5. The moisture expansion values for a 24-hr soaking period at constant temperature, ranged from 0.0004 to 0.009 percent with an average of 0.0039 percent for all samples. The expansion increased rapidly during the first few hours only; thereafter it increased very slowly or remained constant. Little correlation was found between moisture expansion and mineral composition, absorption, specific gravity, or porosity.

6. It is probable that the repeated thermal expansion and contraction of granite resulting from natural weather conditions, is one of the many factors contributing to the eventual disintegration of the stone. These adverse effects of temperature are due mainly to stresses produced by the unequal expansion of layers at different depths and by the unequal expansion of the mineral con- 
stituents. The deterioration resulting from thermal expansion progresses very slowly and probably does not manifest itself appreciably during the normal life of a building, but it may become apparent on certain monumental structures after a long period of time.

There is some evidence that moisture expansion may contribute to the weathering of granite but to a lesser degree than thermal expansion. However, when moisture and thermal expansions occur simultaneously they may cause masonry units to be moved slightly out of position and injure the mortar joints.

The authors thank Peter Hidnert and James B. Saunders of this Bureau for their very helpful suggestions regarding the thermal expansion method used in this investigation.

\section{References}

[1] W. H. C. Bartlett, Experiments on the expansion and contraction of building stone, Am. J. Sci. \& Arts 22, 136 (1832).

[2] A. J. Adie, On the expansion of different kinds of stone from an increase of temperature with a description of the pyrometer used in making the experiments, Trans. Roy. Soc. Edinburgh 13, 366 (1836).

[3] T. M. Reade, Origin of mountain ranges (Taylor and Francis, Ltd. London, 1886).

[4] Report on tests of metals, etc. Watertown Arsenal, U. S. War Dept., 322 to 418 (1895).

[5] W. R. Baldwin-Wiseman and O. W. Griffith, Physical properties of building materials, Proc. Inst. Civil Eng. 3, 179, 290 (1909).

[6] N. E. Wheeler, On the thermal expansion of rock at high temperatures, Trans. Roy. Soc. Can. 3, 4, 19 (1910).

[7] J. H. Griffith, Thermal expansion of typical American rocks, Iowa Eng. Expt. Sta. Bulletin 128 (1936).

[8] T. F. Willis and M. E. DeReus, Thermal volume change and elasticity of aggregates and their effect on concrete, Am. Soc. Testing Materials 39, 919 (1939).

[9] W. H. Johnson and W. H. Parsons, Thermal expansion of concrete aggregate materials, J. Research NBS 32, 101 (1944) RP1578.

[10] Schumann, Protocoll de Verhandlungen der IV General-Versammlung des Vereins Deutscher Cement Fabrikanten (1881).

[11] J. Hirschwald, Handbuch der bautechnischen Gesteingsprufung (Gebrüder Borntraeger, Berlin, 1912).
[12] T. Matsumoto, A study of the effect of moisture content upon the expansion and contraction of plain and reinforced concrete, Univ. of Ill. Eng. Exp. Sta., Bul. No. 126 (Urbana, 1921).

[13] R E. Stradling, Effects of moisture changes on building materials, Dept. Ind. Sci. Research, Bld. Research Bul. 3 (London, 1928).

[14] N. Royen, Naturstenens tekniska egenskaper och dess anvandning till hysbyggnader och dkyddsrumsanlaggningar, Trans. Chalmers Univ. of Technology, Gothenburg, Sweden No. 8 (1942).

[15] D. W. Kessler, A. Hockman, and R. E. Anderson, Physical properties of terrazzo aggregates, NBS Building Materials and Structures Report BMS98 (1943).

[16] D. W. Kessler, H. Insley, and W. H. Sligh, Physicalmineralogical and durability studies on the building and monumental granites of the United States, J. Research NBS 25, 161 (1940) RP1320.

[17] G. E. Merritt, The interference method of measuring thermal expansion, J. Research NBS 10, 59 (1933) RP515.

[18] J. B. Saunders, Expansivity of a Vycor brand glass, J. Research NBS 28, 51 (1942). RP1445.

[19] H. Fizeau, Uber die Ausdehnung starrer Korper durch die Warme, Ann. Physik 128, 564 (1866).

[20] J. B. Saunders, An apparatus for photographing interference phenomena, J. Research NBS 35, 157 (1945) RP1668.

[21] A. Q. Tool, D. B. Lloyd, and G. D. Merritt, Dimensional changes caused in glass by heating cycles, J. Am. Ceramic Soc. 13, 641 (1930).

[22] J. B. Saunders, Interferometer measurements on the expansion of iron, J. Research NBS 33, 75 (1944) RP1597.

[23] Kozu and Saiki, Sci. Rep. Toh. Univ. 3, 2, 205 (1925) as quoted in the Handbook of Physical Constants, Geol. Soc. Am. Special Papers, No. 36, 33 (1942).

[24] Kozu and Ueda, Proc. Imp. Acad. Japan 9, 262 (1933); 10, 25 (1933) as quoted in the Handbook of Physical Constants, Geol. Soc. Am. Special Papers, No. 26,33 (1942).

[25] Kozu, Ueda, and Tsumori, Sci. Rep. Toh. Univ. 3, 10, 222, (1934), as quoted in the Handbook of Physical Constants, Geol. Soc. Am. Special Papers, No. 36, 33 (1942).

[26] L. B. Tuckerman, Optical strain gages and extensometers, Proc. Am. Soc. Testing Materials 23, pt. 2, 602 (1923).

[27] G. P. Merrill, Rocks, rock-weathering and soils, p. 158 to 162 (Macmillan Co., New York, N. Y. 1906.)

[28] R. J. Schaffer, The weathering of natural building stones, Dept. Ind. Sci. Research, Bldg. Research Spec. Report No. 18, London (1932).

Washington, October 27, 1949. 